\title{
Effect of Drowning on Flowering and Seed Setting of Some Sugar Cane Varieties, at Alexandria, Egypt
}

\author{
Gaber A.A. and Safaa S.M. El-Sayed and M.F. Abo El-Fatth ${ }^{1}$
}

\begin{abstract}
Fourteen Varieties of sugar cane were chosen from the field of breeding programme in Sabahia Research Station at Alexandria during 2002 to 2005 seasons to study the effect of drowning on the flowering and seed setting of these varieties. Each variety was planted in two ridges. The length of ridge was 5 meters and the distance between the ridges was $125 \mathrm{~cm}$. The rate of nitrogen fertilization was $100 \mathrm{Kg}$. It was added in three doses. It was after 75, 90 and 120 days from planting date. The rate of doses was equal. Irrigation was every 15 days with the exception of July and August. It was drowned at height $35 \mathrm{~cm}$. It were covered the first and second Internodes. Drainage was every 3 days, and drowning again in the fourth day. All the other cultural practices were conducted for every two ridges in the similar manner whenever possible. The results obtained were as follows:
\end{abstract}

1. The varieties were differed within and between for flowering dates, flowering percentage, seed setting, flowering duration and seedlings number.

2. The seed setting varieties were differed between, while some varieties were seed setting and another were not seed setting.

3. The seed setting were in the first ratoon only, while the plant crop and second ratoon the crossing were not succeeded.

4. The seedlings number which were obtained were varied from one variety to another. Also some varieties did not enable to obtain the seedlings like the prior varieties.

\section{INTRODUCTION}

The world sugar production was depending upon sugar cane in the tropical and subtropical regions and sugar beet in moderate and cold regions. The sugar production from sugar cane was about $73 \%$ from the world sugar production, while sugar beet production was about $27 \%$.

In Egypt sugar cane was the only source of sugar up to 1982. The sugar production did not cover the sugar consumption. The gap between production and consumption was 950.000 tons in 2004 season. It is equal to $37.8 \%$ from total sugar production in 2004 season.
To cover this gap, programs were designed to improve the production of sugar cane and sugar beet through cultural practices and breeding programs.

Many investigators reported that flowering, seed setting and crossing varied from nil to 100 percent, according to the environmental and genetic factors e.g. variety, plant crop or ratooning, growth, vigour, cultural treatments, temperature, relative humidity, ..... etc.(Rao et al. 1973, Nour et al. 1977, Gaber et al. 1981 a and b, Gaber et al. 1984 a, b and c, Gaber et al. 1990, Gaber et al. $1990 \mathrm{a}$ and b, Gaber et al. 1992, Gaber and Rashwan, 1993, Abo El-Fatth et al. 1994, Abo El-Fatth and Gaber 2004, and Gaber and Abo El-Fatth 2004).

The present work was carried out to study the effect of drowning on the flowering dates, flowering percentage, flowering duration, and seed setting and seedling of some sugar cane varieties under the Egyptian conditions in Sabahia Research Station at Alexandria.

\section{MATERIALS AND METHODS}

Fourteen varieties of sugar cane were chosen from the field of breeding programme in Sabahia Research Station at Alexandria during 2002 to 2005 seasons to study the effect of drowning on the flowering dates, flowering percentage, flowering duration, seed setting and seedlings number of the certain varieties under the Egyptian conditions. These varieties were imported from various countries with wide latitude for flowering. 10 varieties from India, 3 varieties from USA and one variety from Dominican Republic.

Each variety was sown in two ridges. The length of ridge was 5.0 meters and the width was $1.25 \mathrm{~m}$. Seed cuttings were sown by one and half row method.

Nitrogen was applied at the rate of $100 \mathrm{~kg}$. per faddangiven as three doses, the first after 75 days from planting and contained one/third the quantity and the second one/third after 90 days from planting and the later after 120 days form planting and contained one/third the quantity.

Irrigation was carried out every 15 days with the exception of July and August was drowning up the first

\footnotetext{
${ }^{1}$ Sugar Crops Research Institute, Agriculture Research Centre, Giza, Egypt,

Received Nov. 14, 2006, Accepted March, 20, 2007
} 
and second internodes (about $35 \mathrm{~cm}$ ). Every three days drainage was conducted and the fourth day irrigation was carried out for leaching the nitrogen content.

All the other cultural practices were carried out for every two ridges in a similar manner whenever possible. The full flowering date, flowering percentage, flowering duration, seed setting and seedlings number was recorded in the former certain varieties.

The flowering percentage were calculated as the following equation:

Flowering percentage $=\frac{\text { Number of plumps flowerd }}{\text { Total nubmer of plumps }} \times 100$

The obtained seeds were sown in pots. Ten pots were planted from each variety. Each pot contained one hundred seeds. The germinated seeds and seedling were counted.

The sown varieties were Co. 312, 508, 513, 527, 975, 1075 and 1148; Co.L. 54, 94 and 57 from India. While C.P. 31-289, 31-294 and 90-28 from USA. While Crystalina from Dominican Republic.

\section{RESULTS AND DISCUSSION}

Table 1 shows that the full flowering dates and the flowering percentage of the certain varieties in plant crop, first and second ratoon from 2002 to 2005 seasons.

It is clear that sugar cane varieties were differed in the flowering dates and flowering percentage from one variety to another and from season to season.

Table 1. Effect of drowning on the flowering dates and flowering percentages in Sabahia Research Station at Alexandria during 2002/2003, 2003/2004 and 2004/2005 seasons.

\begin{tabular}{|c|c|c|c|c|c|c|c|}
\hline \multirow[b]{2}{*}{ No } & \multirow[b]{2}{*}{ Variety } & \multicolumn{6}{|c|}{ Full flowering dates an percentages } \\
\hline & & $\begin{array}{c}\text { Plant } \\
\text { crop } \\
\text { 2002/2003 }\end{array}$ & $\begin{array}{c}\text { Flowering } \\
\%\end{array}$ & $\begin{array}{c}\text { First } \\
\text { ratoon } \\
2003 / 2004\end{array}$ & $\begin{array}{c}\text { Flowering } \\
\%\end{array}$ & $\begin{array}{c}\text { Second } \\
\text { ratoon } \\
2004 / 2005 \\
\end{array}$ & $\begin{array}{c}\text { Flowering } \\
\%\end{array}$ \\
\hline 1 & Co. 312 & $30-1-2003$ & 100.0 & - & - & - & - \\
\hline 2 & 508 & $8-3-2003$ & 100.0 & $21-6-2004$ & 100.0 & - & - \\
\hline 3 & 513 & 29-3-2003 & 75.5 & $25-2-2004$ & 55.0 & - & - \\
\hline 4 & 527 & $28-4-2003$ & 66.8 & - & - & $25-3-2005$ & 42.8 \\
\hline 5 & 975 & $29-3-2003$ & 95.0 & - & - & $30-5-2005$ & 75.3 \\
\hline 6 & 1075 & $8-3-2003$ & 100.0 & $1-5-2004$ & 100.0 & $25-3-2005$ & 100.0 \\
\hline 7 & 1148 & $17-5-2003$ & 100.0 & $1-5-2004$ & 100.0 & $30-1-2005$ & 100.0 \\
\hline 8 & Co.L.54 & $25-1-2003$ & 85.0 & $5-4-2004$ & 65.5 & - & - \\
\hline 9 & 83 & $28-12-2003$ & 100.0 & $25-2-2004$ & 100.0 & $10-2-2005$ & 100.0 \\
\hline 10 & 87 & $28-12-2003$ & 45.7 & $25-2-2004$ & 35.7 & $15-4-2005$ & 55.7 \\
\hline 11 & C.P.31-289 & - & - & $25-2-2004$ & 96.0 & $5-4-2005$ & 87.0 \\
\hline 12 & $31-294$ & - & - & $12-5-2004$ & 100.0 & - & - \\
\hline 13 & $50-28$ & - & - & $21-5-2004$ & 10.8 & - & - \\
\hline 14 & Crystalina & $4-5-2003$ & 34.0 & $1-6-2004$ & 14.6 & - & - \\
\hline
\end{tabular}


Table 2 indicates that crossing, seed setting and seedlings number of 14 varieties of sugar cane in plant crop, first and second ratoon from 2002 to 2005 seasons.
It is clear that the crossing and seed setting were not succeeded with the exception of first ratoon. The number of seedlings was differed from one variety to another except 5 varieties.

Table 2. Effect of drowning on the crossing, seed setting and seedlings number in Sabahia Research Station at Alexandria during 2002/2003, 2003/2004 and 2004/2005 seasons.

\begin{tabular}{|c|c|c|c|c|c|c|c|}
\hline \multirow[t]{2}{*}{ No } & \multirow[t]{2}{*}{ Variety } & \multicolumn{2}{|c|}{$\begin{array}{l}\text { Plant crop } \\
2002 / 2003 \\
\end{array}$} & \multicolumn{2}{|c|}{$\begin{array}{c}\text { First ratoon } \\
2003 / 2004 \\
\end{array}$} & \multicolumn{2}{|c|}{$\begin{array}{c}\text { Second ratoon } \\
2004 / 2005\end{array}$} \\
\hline & & 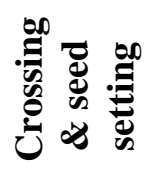 & 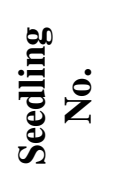 & 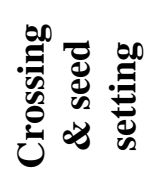 & 象 & 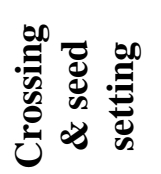 & 弟 \\
\hline
\end{tabular}

1 Co. $312 \mathrm{X}$ ?

2

3

4

5

6

7

$8 \quad$ Co.L. 54 X?

9

10

11 C.P.31-289

$\mathrm{X}$ ?

$12 \quad 31-294 X ?$

$1350-28 X$ ?

14 Crystalina X?
1

23

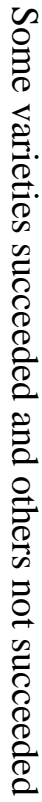

164

$Z$
0
0
0
0
0
0
0
0
0
2

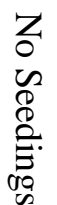

7

74

2

7

53 
Table 3 reveals that the monthly average of maximum and minimum temperature degrees, mean and range. Also, it is reported the monthly average of maximum and minimum of relative humidity, mean and range from January 2002 to December 2005 at Alexandria.

Regarding to Table 3 shows that the temperature degrees and relative humidity were differed form one month to another, one day to other and from one season to another. It is due to the variation of environmental conditions. Subsequently, it is referred to the prior varieties. Beside the genetic variations and the interaction between genotypes and climatic conditions.
Figure 1 clears the average of flowering percentages in the certain varieties. It was begun from 10.8 to 100.0 percent. The flowering percentages were differed from one variety to another. It was divided to four groups as follows:

1. Very high flowering percentage: It was $100 \%$. It contains six varieties, were Co. 312, Co. 508, Co. 1075, Co. 1148, Co.L. 83 and C.P. 31-294.

2. High flowering percentages: It was between 75.2 to 91.5\%. It contains 3 varieties, were Co.L. 54, Co. 975 and C.P. 31-289.

3. Middle flowering percentages: It was between 45.7 to $65.2 \%$. It contains 3 varieties, were Co.L. 87, Co.527 and Co. 513.

Table 3. Temperature degrees and relative humidity from 202 to 2005 seasons at Sabahia Research Station at Alexandria, Egypt.

\begin{tabular}{|c|c|c|c|c|c|c|c|c|c|}
\hline \multirow{3}{*}{ No. } & \multirow{3}{*}{ Month } & \multicolumn{4}{|c|}{ Temperature degrees } & \multicolumn{4}{|c|}{ Relative humidity } \\
\hline & & \multicolumn{2}{|c|}{ Average of } & \multirow{2}{*}{ Mean } & \multirow{2}{*}{ Range } & \multicolumn{2}{|c|}{ Average of } & \multirow{2}{*}{ Mean } & \multirow{2}{*}{ Range } \\
\hline & & Max. & Min. & & & Max. & Min. & & \\
\hline 1 & January2002 & 17.4 & 7.3 & 12.4 & 10.1 & 98.0 & 68.0 & 83.0 & 30.0 \\
\hline 2 & February & 19.6 & 8.4 & 14.0 & 11.2 & 99.0 & 70.0 & 84.0 & 29.0 \\
\hline 3 & March & 22.8 & 10.1 & 16.5 & 12.7 & 98.0 & 57.0 & 77.0 & 41.0 \\
\hline 4 & April & 27.2 & 12.7 & 19.5 & 14.5 & 99.0 & 52.0 & 76.0 & 47.0 \\
\hline 5 & May & 29.3 & 17.1 & 22.5 & 12.2 & 98.0 & 50.0 & 75.0 & 48.0 \\
\hline 6 & June & 37.1 & 21.3 & 29.2 & 15.8 & 72.0 & 22.0 & 47.0 & 50.0 \\
\hline 7 & July & 34.5 & 23.1 & 28.8 & 11.4 & 97.0 & 58.0 & 77.0 & 39.0 \\
\hline 8 & August & 33.6 & 23.4 & 28.5 & 10.2 & 97.0 & 62.0 & 79.0 & 35.0 \\
\hline 9 & September & 34.0 & 21.0 & 27.0 & 13.0 & 96.0 & 50.0 & 73.0 & 46.0 \\
\hline 10 & October & 29.3 & 18.2 & 23.8 & 11.1 & 97.0 & 61.0 & 79.0 & 36.0 \\
\hline 11 & November & 26.2 & 12.8 & 19.5 & 13.4 & 96.0 & 62.0 & 79.0 & 34.0 \\
\hline 12 & December & 21.0 & 10.1 & 15.6 & 10.9 & 93.0 & 58.0 & 76.0 & 35.0 \\
\hline 13 & January 2003 & 21.5 & 9.8 & 15.6 & 11.7 & 96.0 & 55.0 & 76.0 & 41.0 \\
\hline 14 & February & 23.8 & 12.2 & 18.3 & 11.6 & 99.0 & 72.0 & 75.0 & 27.0 \\
\hline 15 & March & 20.1 & 9.3 & 14.7 & 10.8 & 97.0 & 57.0 & 77.0 & 40.0 \\
\hline 16 & April & 25.8 & 13.2 & 19.5 & 12.6 & 96.0 & 46.0 & 71.0 & 50.0 \\
\hline 17 & May & 30.1 & 16.8 & 23.5 & 13.3 & 98.0 & 56.0 & 77.0 & 42.0 \\
\hline 18 & June & 31.9 & 19.2 & 25.6 & 12.7 & 100.0 & 58.0 & 79.0 & 42.0 \\
\hline 19 & July & 32.8 & 23.3 & 28.0 & 19.5 & 96.0 & 62.0 & 79.0 & 34.0 \\
\hline 20 & August & 40.3 & 22.8 & 31.6 & 17.5 & 98.6 & 66.2 & 42.2 & 32.4 \\
\hline 21 & September & 32.3 & 20.3 & 26.3 & 12.0 & 96.0 & 56.0 & 76.0 & 40.0 \\
\hline 22 & October & 31.7 & 18.1 & 24.9 & 13.6 & 100.0 & 50.0 & 75.0 & 50.0 \\
\hline 23 & November & 23.7 & 12.0 & 17.9 & 11.7 & 100.0 & 82.0 & 91.0 & 18.0 \\
\hline 24 & December & 21.2 & 10.6 & 15.9 & 10.6 & 98.0 & 61.0 & 79.0 & 37.0 \\
\hline
\end{tabular}

Continued 
Table 3. (Continued)

\begin{tabular}{|c|c|c|c|c|c|c|c|c|c|}
\hline \multirow{3}{*}{ No. } & \multirow{3}{*}{ Month } & \multicolumn{4}{|c|}{ Temperature degrees } & \multicolumn{4}{|c|}{ Relative humidity } \\
\hline & & \multicolumn{2}{|c|}{ Average of } & \multirow{2}{*}{ Mean } & \multirow{2}{*}{ Range } & \multicolumn{2}{|c|}{ Average of } & \multirow{2}{*}{ Mean } & \multirow{2}{*}{ Range } \\
\hline & & Max. & Min. & & & Max. & Min. & & \\
\hline 25 & January2004 & 17.9 & 7.8 & 13.3 & 10.1 & 98.0 & 66.0 & 82.0 & 32.0 \\
\hline 26 & February & 24.9 & 13.4 & 19.2 & 11.5 & 100.0 & 73.0 & 87.0 & 27.0 \\
\hline 27 & March & 23.9 & 11.2 & 17.3 & 12.7 & 99.0 & 58.0 & 78.0 & 41.0 \\
\hline 28 & April & 26.0 & 12.0 & 19.2 & 14.0 & 99.0 & 51.0 & 75.0 & 28.0 \\
\hline 29 & May & 28.1 & 16.5 & 22.3 & 11.6 & 98.0 & 50.0 & 74.0 & 48.0 \\
\hline 30 & June & 30.1 & 19.4 & 24.8 & 10.7 & 99.0 & 62.0 & 81.0 & 37.0 \\
\hline 31 & July & 33.0 & 22.1 & 27.6 & 10.9 & 99.0 & 61.0 & 80.0 & 38.0 \\
\hline 32 & August & 33.3 & 22.0 & 27.7 & 11.3 & 99.0 & 64.0 & 81.0 & 35.0 \\
\hline 33 & September & 31.5 & 19.6 & 25.6 & 11.9 & 99.0 & 58.0 & 78.0 & 41.0 \\
\hline 34 & October & 31.4 & 17.3 & 24.3 & 14.1 & 89.0 & 37.0 & 63.0 & 52.0 \\
\hline 35 & November & 26.0 & 15.2 & 20.6 & 10.8 & 99.0 & 62.0 & 80.0 & 37.0 \\
\hline 36 & December & 20.1 & 10.5 & 15.8 & 9.6 & 98.0 & 60.0 & 78.0 & 38.0 \\
\hline 37 & January2005 & 16.7 & 6.6 & 12.3 & 10.1 & 99.0 & 69.0 & 82.0 & 30.0 \\
\hline 38 & February & 19.6 & 8.9 & 14.3 & 10.7 & 98.0 & 67.0 & 82.0 & 31.0 \\
\hline 39 & March & 21.8 & 12.2 & 17.1 & 9.6 & 95.0 & 57.0 & 76.0 & 38.0 \\
\hline 40 & April & 23.7 & 13.3 & 18.5 & 10.4 & 99.0 & 56.0 & 77.0 & 43.0 \\
\hline 41 & May & 28.5 & 15.9 & 22.2 & 12.6 & 99.0 & 57.0 & 78.0 & 42.0 \\
\hline 42 & June & 30.1 & 19.5 & 24.8 & 10.6 & 99.0 & 64.0 & 82.0 & 35.0 \\
\hline 43 & July & 32.3 & 21.5 & 26.9 & 10.8 & 100.0 & 64.0 & 82.0 & 36.0 \\
\hline 44 & August & 32.8 & 23.1 & 28.0 & 9.7 & 89.0 & 58.0 & 73.0 & 31.0 \\
\hline 45 & September & 33.1 & 20.7 & 26.7 & 12.4 & 97.0 & 57.0 & 77.0 & 40.0 \\
\hline 46 & October & 27.7 & 17.4 & 22.5 & 10.3 & 96.0 & 61.0 & 78.0 & 35.0 \\
\hline 47 & November & 24.0 & 13.3 & 18.6 & 10.7 & 97.0 & 59.0 & 78.0 & 38.0 \\
\hline 48 & December & 20.0 & 10.0 & 17.9 & 10.0 & 97.8 & 60.0 & 78.8 & 37.8 \\
\hline
\end{tabular}

- Monthly Agricultural Meteorology from 2002 to 2005 seasons, Agricultural Research Centre, Giza, Cairo, Egypt.

4. Lower flowering percentages: It was between 10.8 to 24.3. It contains 2 varieties, were C.P. 50-28 and Crystalina.

Figure 2 shows that the average of flowering duration of the mentioned varieties of sugar cane. It was started from December to June during 2002 to 2005 seasons. It was differed from one variety to another. It was divided to four groups as follow:

1. Very short duration: It was between 7 to 14 days. It contained 3 varieties, were Co. 312, C.P. 31-294 and C.P. 50-28.

2. Short duration: It was between 27 to 40 days. It contains 4 varieties, were as Co. 513, Co. 527, C.P. 31-289 and Crystalina.
3. Middle duration: It was between 53 to 70 days. It contains 4 varieties, were Co. 975 , Co. 1075 , Co.L. 54 and Co.L. 83.

4. Long duration: It was between 103 to 107 days. It contains 3 varieties, were Co. 508, Co. 1148 and Co.L. 87 .

Figure 3 cleared that the effect of drowning on the seedlings number in the first ratoon of the preceding varieties of sugar cane. It was differed from one variety to another. It was divided to four groups as follows:

1. Low seedlings number: It was between 1 to 7 seedlings. It contains 5 varieties, were Co. 508, Co.L. 54, Co.L. 87, C.P. 31-294 and C.P. 50-28.

2. Middle seedlings number: It was between 20 to 50 seedlings. It contains one variety. It was Co. 513. 
3. High seedlings number: It was between 41 to 100 seedlings. It contains two varieties, were Crystalina and C.P. 31-289.

4.Very high seedlings number: It was over 100 seedlings. It contains one variety. It was Co.L. 83.

The above results seems to add more support to the finding of Humbert (1968) who found that sugar cane has remarkable thirst for water during the vegetative growth in order to physiological maturing in induce flowering. It is a crop with relatively high consumptive use efficiency. It is still grown in Egypt because the irrigation and drainage projects developed through the previous centuries.

Also, Humbert (1968) reported that the timing of irrigation rounds depends on the water needs of the cane plant, which vary depending on the season, the availability of water and storage capacity of soils in which the cane's root system is active. He added that the prior studies in Hawaii and Mexico indicate that daily water requirements of sugar cane vary from 0.35 inches per day in hot, dry summer months to 0.10 inches per day in the cold, cloudily winter months.

In this connection Alexander (1973) stated that water management in the sugar cane is the best factor for flower prevention, acceleration and delaying.

Also, Humbert (1968) and Alexander (1973) indicate that flowering of sugar cane are the highest where adequate attention has been given to the water requirements. Many authors agree that controlled water supply during the critical period of flower induction is the most effective means of flower control available to cane grower (Humbert 1968).

In Egypt, before the high dam the flooding method in water being forced to spread over vast areas was used during the season of high stream flow. But, after the high dam, the various systems of surface irrigation and other methods were used.

Variations in weather are cause of considerable variability in growth rates, sugar storage, flowering and tillering incidence (Tables 1 and 3 Figures 1 and 3).

flow. But, after the high dam, the various systems of surface irrigation and other methods were used.

Variations in weather are cause of considerable variability in growth rates, sugar storage, flowering and tillering incidence (Tables 1 and 3 Figures 1 and $3)$.

In this aspect it could be referred to Humbert (1968), Gaber et al. (1984c), Gaber and Rashwan (1990), Gaber et al. (1992), El-Manhaly et al. (1981) and (1987) who found that sugar cane flowering vary tremendously due to many factors as follow:

(1) Variable soil fertility.

(2) Varieties used.

(3) Cultural practices.

(4) Use of fertilizers.

(5) Irrigation.

(6) Control of weeds.

(7) Pests and Diseases.

(8) And other factors.

In Egypt, the sugar cane flowering is considered to be new direction in cane breeding programme. The above mentioned data agree with those reported by Brett (1950) and Climents (1964) who reported that the optimum conditions for floral initiation and tasselling in sugar cane.

It was concluded from Rao et al. (1968) that the conditions of temperature, humidity and day length in Alexandria, Egypt is ideal for floral induction (Rao et al., 1973).

In Egypt, the trials of sugar cane flowering were succeeded with controlling of irrigations regime and nitrogen fertilization at Alexandria (Rao et al., 1973, Nour et al., 1977 and Allam et al., 1977).

The varieties of sugar cane differ widely in the physiological characters, especially the occurrence of flowering under Egyptian conditions (Gaber et al., 1981a).

The end product of this study, to maximize the crossing period we must to select the sugar cane varieties which flowering duration is long as Co. 508, Co. 1148 and Co.L. 87, and seedlings number were high or very high as Co.L. 83 and C.P. 31-289.

At Alexandria the heavy raining were during December and January. It is a difficult to work the sugar can crossing. Beside the temperature degrees is very low (Table 3). The adequate temperature degrees for crossing is between 18 to $32^{\circ} \mathrm{C}$ (Gaber et al., 1984c). We must to choose the days or the periods, which the temperature degrees were between 18 to $32^{\circ} \mathrm{C}$. 


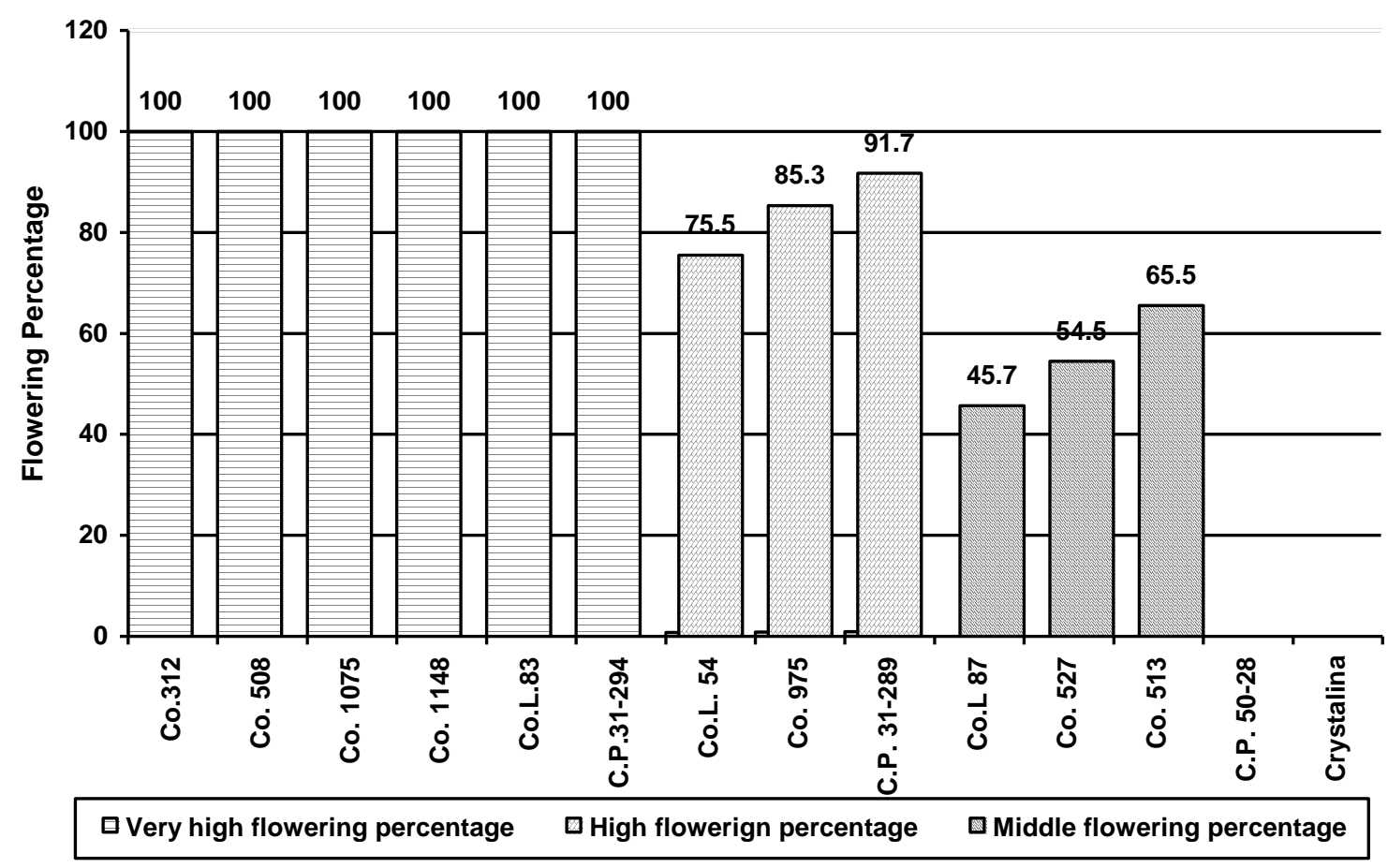

Figure I: Effect of drowning on the average flowering percentage of some sugar cane varieties in Sabahia Res. St. At Alex. From 2002 to 2005 seasons.

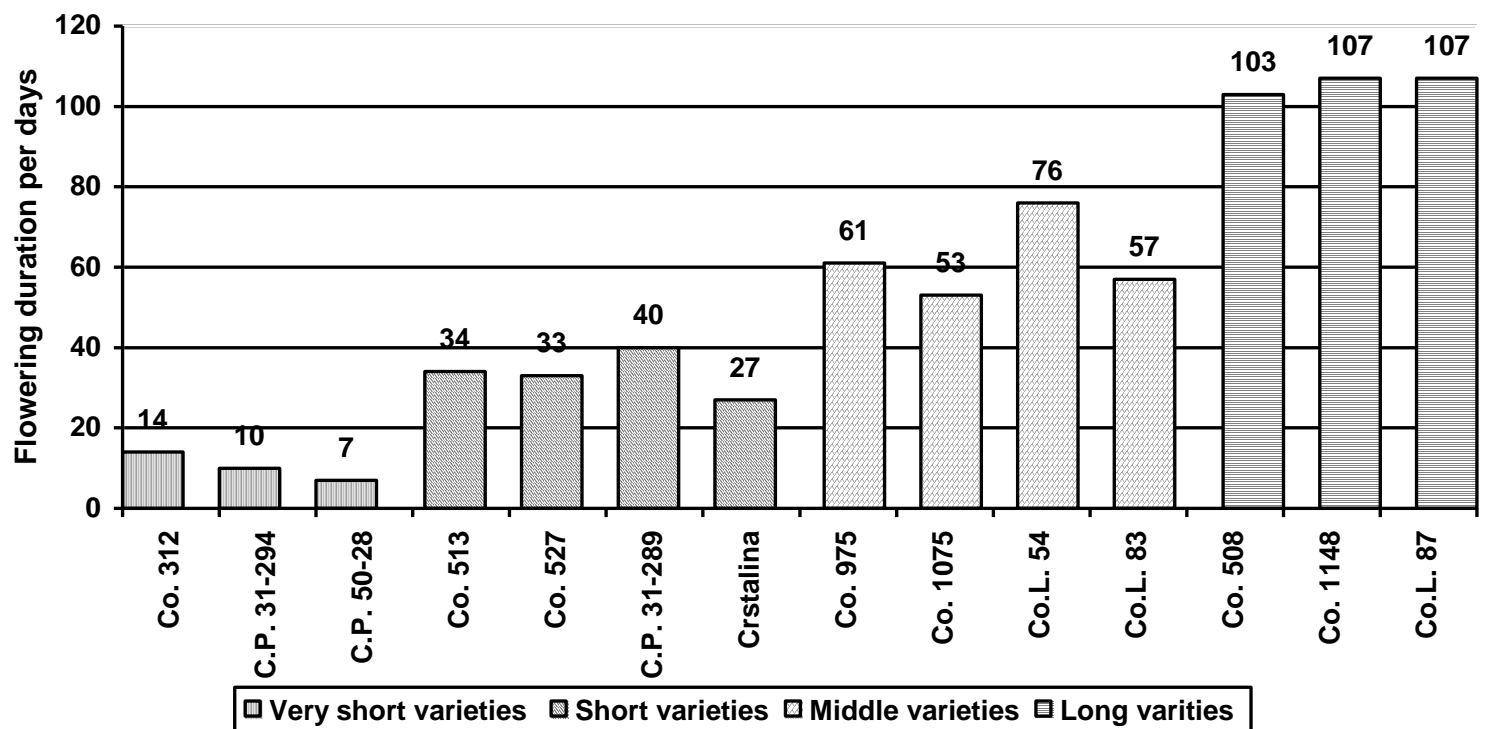

Figure 2: Effect of drowning on the average flowering duration of some sugar cane varieties in Sabahia Res. St. at Alex. From 2002 to 2005 seasons. 


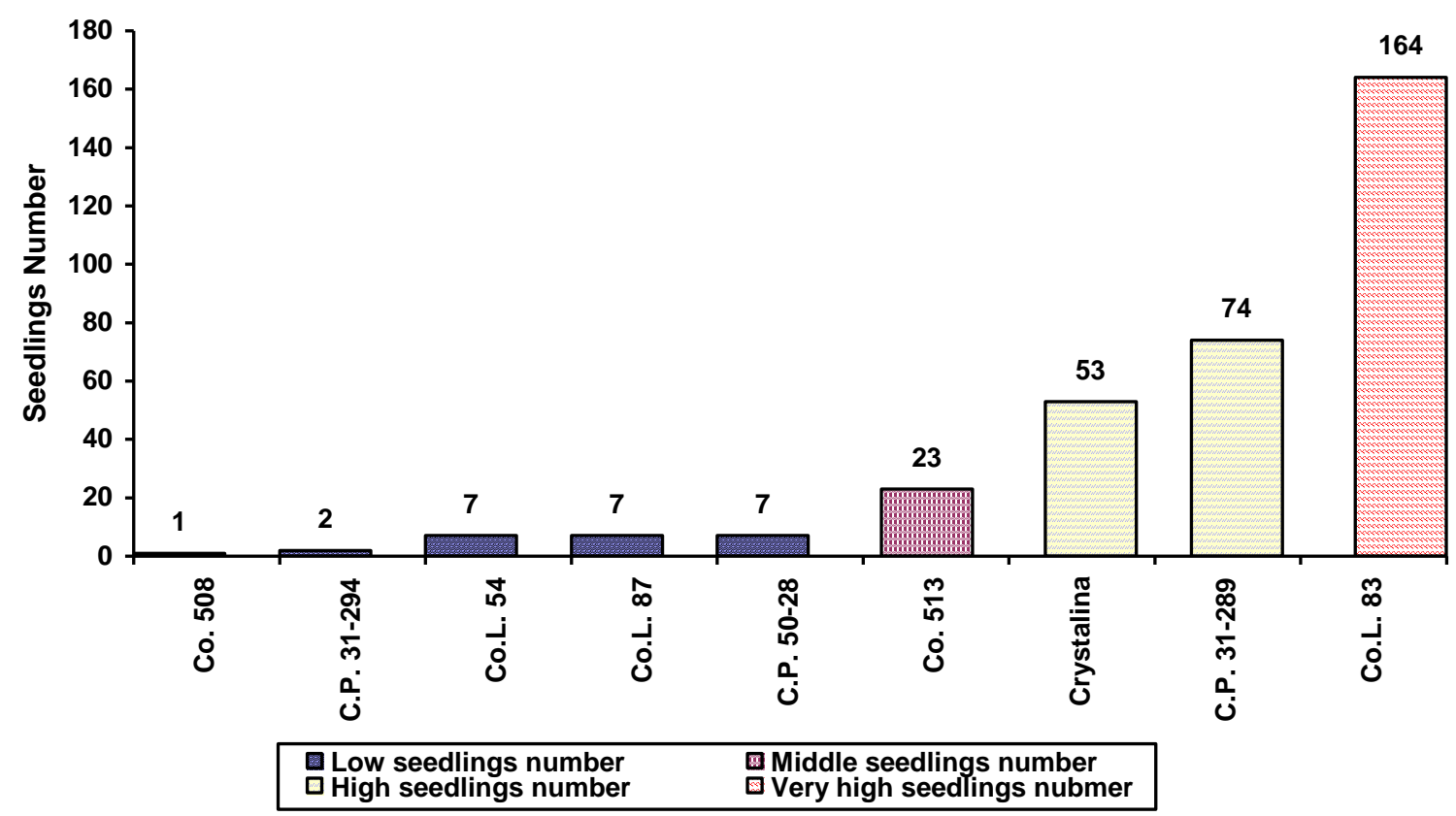

Figure 3: Effect of drowning on the seedlings of some sugar cane varieties from plant crop, first and second ratoon during 2002/2003, 2003/2004 and 2004/2005 seasons.

\section{REFERENCES}

Abou El-Fatth, M.F.; A.A. Gaber; Y.H.M. Tawfic and N.M.A. El-Talkhawy (1994). Effect of sowing dates on flowering and seed setting of some sugar cane varieties at Alexandria. Alex. Sci. Exch., Vol. 15, pp. 105-125.

Abou El-Fatth, M.F. and A.A. Gaber (2004). Effect of ratooing on flowering and seed setting on some sugar cane varieties at Alexandria, Egypt. Alex. Sci. Exch., Vol. 25, No. 4, pp. 765-772.

Allam, A.I.; A.H. Nour and T.A. Fayed (1977). The flowering behaviour of latitudinally displaced sugar cane varieties. Proc. ISSCT, XVI 283-290.

Alexander, A.G (1973). Sugar cane physiology, flowering. A. Comprehensive study of Saccharum source to sink system. El Sevier Scientific Publishing Co., London, England, pp. 523-572.

(Annual peport of Suger crops,2004) Sugar crops and sugar production in Egypt. Annual Report of Sugar Crops 2004. The Central council for sugar crops. Ministry of Agriculture and Land Reclamation.

Brett, P.G. (1950). Flowering and pollen fertility in relation to sugar cane breeding in Natal. Proc. TSSCT, 7, 43-56.

Climents, H.F. and M. Awado (1964). Factors effecting the flowering of sugar cane. Indian. J. Sugar Cane Research and Development. Vol. 8: 140-159.
El-Manahly M.A., A.H. Nour; A.A. Gaber and F.M. Abd ElGhaffar (1981). Evaluation of some sugar cane varieties to flower under the Egyptian conditions. Agric. Res. Rev. Vol. 59, No. 8, 17-26.

El-Manhaly, M.A.; M.F. Maareg; A.A. Gaber and M.A. Farag (1987). Sugar cane flowering and seed setting. Alex. Sci. Exch., Vol. 18, No. 2: 129-139.

Gaber, A.A.; H.A. Mesbah; A.H. Nour and M.A. Abdel Rassol (1981a). Correlation between yield and some morphological, physiological, chemical characters and borer infestations in thirty four varieties of sugar cane at Alexandria. Agric. Res. Rev., Vol. 59, No. (8): 99-112.

Gaber, A.A.; H.A. Mesbah; M.A. El-Manhaly and A.H. Nour (1981b). Relationship between number of tillers, sugar content and levels of borers infestation of some sugar cane varieties. Agric. Res. Rev., Vol. 59, No. (8): 113126.

Gaber, A.A.; I.M. Fayed; T.A. Abd El-Latif and M.A. Farag (1984a). Effect of some growth regulators on flowering habit and some economical characters on sugar cane. Second Conf. ARC. Giza 9-11 April, x12.

Gaber, A.A.; R.A. Eskander and M.A. Farag (1984b). Relationship between flowering and some economic characters of nine sugar cane varieties. Second Conf. ARC. Giza 9-11 April, X14

Gaber, A.A.; S.H. Farrg; M.F. Abou El-Fatth and S.G. Ibrahim (1984c). Effect of locations and environmental 
conditions on the flowering induction in sugar cane. Second Conf. ARC. Giza 9-11 April, X15.

Gaber, A.A. and Laila, M.A. Rashwan (1990). Effect of temperature and relative humidity on tillering and borers infestation of some sugar cane varieties at Alexandria. Com. In Sci. \& Dev., Vol. 31: 1-12.

Gaber, A.A.; M.A. Farag and M.F. Abou El-Fatth (1990b). Relationship between plant weight and some agronomic characters in plant crop and first ratoon of eight sugar cane varieties at Alexandria. Com. In Sci. \& Dev. Res., Vol. 31: 55-81.

Gaber, A.A.; Samia S. El-Maghraby; M.H. El-Deeb; Fauzia H. El-Helbawi and M.F. Abou El-Fatth (1990a). Correlation between stalk weight and some morphological characters in plant crop and first ratoon of some sugar cane varieties at Alexandria. Annals of Agric. Sci., Moshtohor, Vol. 28, No. 4: 1947-1973.

Gaber, A.A.; M.F. Abou El-Fatth and A.H. Nour (1992). Flowering behaviour of some sugar cane varieties at Alexandria, Egypt. Alex. Sci. Exch., Vol. 13, No. 4: 831844.

Gaber, A.A. and Laila M.A. Rashwan (1993). Effect of varietal geographical sources on yield, components, agronomic characters and borers infestations of some sugar cane varieties at Alexandria, Egypt. Com. In Sci. \& Dev. Res., Vol. 42, No. 643: 149-164.

Gaber, A.A. and M.F. Abou El-Fatth (2004). Crossing of some sugar cane varieties under the Egyptian conditions. Alex. Sci. Exch., Vol. 25, No. 4, pp. 757-764.

Humbert, R.O. (1968). The growing of sugar cane. Irrigation of sugar cane. Chapter 5: 310-397.

Israelsen, D.W. and V.E. Hansen (1962). Irrigation principles and practices. $3^{\text {rd }}$ ed. John Willey and Sons, New York, $447 \mathrm{pp}$

Nour, A.A.; A.A. Gaber; J.T. Rao and T.M. Elamany (1977). Flowering of sugar cane and breeding prospects in Egypt. Agric. Res. Rev., pp. 77-85.

Paliatseas, E.D. (1962). Further studies on flowering of sugar cane in Louisiana. Proc. ISSCT, 11, 504-515.

Rao, J.T. and T.N. Krishnumurthy (1968). Accelerating genetic improvement in sugar cane. Ind. Jour. Of Gene. And Plant breeding 28(A), 88-96.

Rao, J.T.; A.H. Nour and M.A. El-Manhaly (1973). Flowering of sugar cane in Egypt. Int. Sugar Jour., 75: 241244. 


\section{الملخص العربي}

\section{تأثير الغرق على أزهار وعقد البذور لبعض أصناف قصب السكر للغرس والخلفة الأولى والخلفة الثانية}

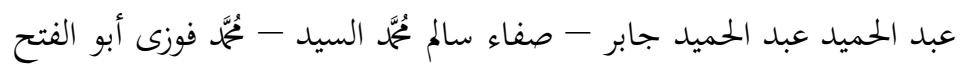

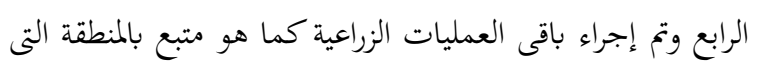

زرعت بها هذه الأصناف وتم الحصول على النتائج التالية:

1

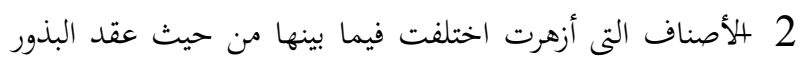

فقد تم العقد في بعض الأصناف ولم يتم العقد في البعض الآخر.

3

4 لختلفت الأصناف فيما بينها من حيث الغرس والخلفة الأولى

والثانية.

5 لا يتم عقد للبذور والحصول على بادرات إلا فن الخلفة الأولى

فقط.
تم اختبار 14 صنفاً من أصناف قصب السكر من حقل التزبية

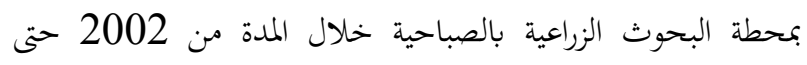

2005 وذلك لدراسة تأثير الغرق على إزهار وعقد البذور وعدد البراديا

البادرات لهذه الأصناف - كل صنف تم زراعته في خطين طول الحنط

5م والمسافة ما بين كل خط وآخر 125سم ولقد تم التسميد بععدل

100 كجم على ثلاث دفعات الأولى بعد 75 يوماً من الزراعة

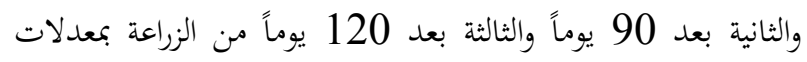

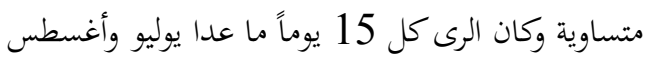
فتم غمر الأرض لمسافة 35سم أى تم تغطية العقلة الأولى والثانية

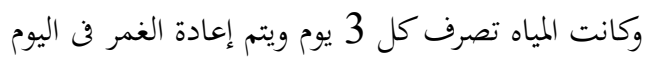

